\begin{tabular}{|c|l|}
\hline Title & $\begin{array}{l}\text { Surface retained organic matter of Microcystis aeruginosa inhibiting coagul ation with polyal uminum chloride in } \\
\text { drinking water treatment }\end{array}$ \\
\hline Author(s) & Takaara, Tomoko; Sano, Dai suke; Masago, Y oshifumi; Omura, Tatsuo \\
\hline Citation & $\begin{array}{l}\text { Water Research, 44(13), 3781-3786 } \\
\text { https://doi.org/40.1016j.watres.2010.04.030 }\end{array}$ \\
\hline Issue Date & 2010-07 \\
\hline Doc URL & http:/hdl.handle.net/2115/49828 \\
\hline Type & article (author version) \\
\hline File Information & WR4413_3781-3786.pdf \\
\hline
\end{tabular}

Instructions for use 
For Submission to Water Research as a Research Paper

\section{Surface-retained organic matter of Microcystis aeruginosa inhibiting coagulation with polyaluminum chloride in drinking water treatment}

By

Tomoko Takaara $^{a, b^{*}}$, Daisuke Sano ${ }^{c}$, Yoshifumi Masago ${ }^{b}$ and Tatsuo Omura ${ }^{b}$

${ }^{a}$ Department of Civil Engineering, Fukushima National College of Technology, 30,

Nagao, Tairakamiarakawa, Iwaki, Fukushima, 970-8034, Japan

${ }^{b}$ Department of Civil and Environmental Engineering, Graduate School of Engineering,

Tohoku University, 6-6-06, Aoba, Aramaki, Aoba-ku, Sendai, Miyagi 980-8579, Japan

${ }^{c}$ Division of Built Environment, Graduate School of Engineering, Hokkaido University,

North 13, West 8, Kita-ku, Sapporo, 060-8628, Japan

\section{*Corresponding author:}

Tomoko Takaara, Ph.D.

Mailing address:

Department of Civil Engineering, Fukushima National College of Technology 
30, Nagao, Tairakamiarakawa, Iwaki, Fukushima, 970-8034, Japan.

Tel: +81(246)46-8034.

Fax: +81(246)46-0843.

E-mail: takaara@fukushima-nct.ac.jp 


\section{ABSTRACT}

Algogenic organic matter produced by the excess growth of cyanobacteria in semi-closed water areas causes coagulation inhibition in drinking water production. In this study, hydrophilic substances of Microcystis aeruginosa, which were mainly composed of lipopolysaccharide (LPS) and RNA, were prepared, and the involvement of these cyanobacterial hydrophilic substances in coagulation inhibition was investigated. As a result, it was found that the negatively charged hydrophilic substances with a molecular weight higher than $10 \mathrm{kDa}$ have a significant role in coagulation inhibition. Further fractionation of cyanobacterial hydrophilic substances revealed that surface-retained organic matter (SOM), including LPS, could exhibit a potent inhibitory effect on the coagulation using polyaluminum chloride ( $\mathrm{PACl})$, presumably because of the direct interaction of hydrophilic SOM with cations originated from $\mathrm{PACl}$, which could impede the hydrolysis of the coagulant.

Keywords: Microcystis aeruginosa, surface-retained organic matter (SOM), coagulation inhibition, polyaluminum chloride (PACl), lipopolysaccharide (LPS) 


\section{Introduction}

Semi-closed water areas such as reservoirs are the main sources of drinking water in urbanized areas. The eutrophication of the semi-closed water areas has been one of the critical issues in drinking water production, because it brings about the excess growth of cyanobacteria, thereby causing various disorders in drinking water treatment processes (Widrig et al., 1996; Hitzfeld et al., 2000; Ma et al., 2002; Westerhoff et al., 2005; Huang et al., 2009). In particular, coagulation efficiency at the destabilization step is fairly susceptible to the presence of algogenic organic matter (AOM) in source water (Bernhardt et al., 1991; Cheng and Chi, 2003; Pivokonsky et al., 2006). The reduction of coagulation efficiency caused by AOM could be temporarily overcome by increasing coagulant dose, which creates subsidiary problems, including an increased cost for the coagulant and sludge treatment. It is important to elucidate the inhibitory mechanism caused by AOM, which could contribute to the establishment of effective countermeasures to coagulation inhibition.

One of the proposed inhibitory mechanisms is that AOM can form complexes with cations originated from coagulant, which seriously deteriorates the coagulation capability (Bernhardt et al., 1987; Bernhardt et al., 1991). Our previous studies showed that proteins from Microcystis aeruginosa consume polyaluminum chloride ( $\mathrm{PACl})$ in the coagulation process due to the formation of chelate complexes with the coagulant 
(Takaara et al., 2005; Takaara et al., 2007). Since cyanobacterial proteins are mainly located inside the cell, it was speculated that these inhibitory proteins released by cell lysis or prechlorination significantly affect coagulation efficiency. However, the presence of these cyanobacterial inhibitory proteins does not fully explain the involvement of AOM in coagulation inhibition, because the reduction of coagulation efficiency without accompanying cell destruction also has been reported (Ma et al., 2007). The presence of inhibitory organic matter located on the outside of cyanobacterial cells would be one of the plausible explanations for the nonproteineous substance-induced coagulation inhibition (Hoyer et al., 1985; Bernhardt et al., 1987). The exterior-located organic matter can be categorized into surface-retained organic matter (SOM) and extracellular organic matter (EOM), and EOM has been extensively studied as an inhibitory substance (Liu and Bernhardt, 1991). On the other hand, the involvement of SOM in coagulation inhibition has not been investigated well because it has been technically difficult to analyze the contribution of SOM to coagulation inhibition separately from EOM and intracellular organic matter (IOM). The evaluation of cyanobacterial SOM as an inhibitory substance could be very informative to address the problems of the reduction of coagulation efficiency in water treatment processes.

In this study, we analyzed the inhibitory potential of SOM produced by $M$. aeruginosa against the coagulation with PACl. Firstly, in order to confirm the presence of inhibitory substances on the cell surface of a laboratory strain of $M$. aeruginosa, the 
removal rates of $M$. aeruginosa cells and kaolin under various dosage of $\mathrm{PACl}$ was evaluated. Then, hydrophilic organic substances, including SOM, were extracted from M. aeruginosa cells by a phenol-water extraction, and fractionated by ethanol precipitation, ultrafiltration and ion exchange chromatography. RNase A treatment was also employed to eliminate RNA co-extracted with SOM in the hydrophilic organic substances from $M$. aeruginosa cells. The involvement of the extracted SOM in the coagulation inhibition was evaluated by the coagulation test using a kaolin suspension in the presence of the extracted SOM.

\section{Materials and methods}

The preparation procedure of SOM samples for the evaluation of inhibitory potential on the coagulation with $\mathrm{PACl}$ is summarized in Fig. 1. Details of the sample preparation and the coagulation test are described below.

\section{Cultivaiton of M. aeruginosa}

M. aeruginosa NIES-91 strain was provided by the National Institute for Environmental Studies, Japan. M. aeruginosa was cultured in a $500 \mathrm{~mL}$ conical flask containing $250 \mathrm{~mL}$ MA medium at $\mathrm{pH} 8.6$ (Ichimura, 1976) under illumination of a fluorescent lamp (4000 Lux) with a cycle of $12 \mathrm{hrs}$ light and $12 \mathrm{hrs}$ dark at $30^{\circ} \mathrm{C} . \mathrm{M}$. 
aeruginosa was harvested in a steady growth phase when its optical density at $660 \mathrm{~nm}$ $\left(\mathrm{OD}_{660}\right)$ reached $0.90 \pm 0.05$. The excess production of a slime layer and floating colony formation of M. aeruginosa were not observed.

\section{Coagulation test of $M$. aeruginosa cells}

Harvested $M$. aeruginosa cells in a steady growth phase were concentrated by being centrifuged at $1500 \mathrm{x}$ g for $10 \mathrm{~min}$. The pellet was suspended in $50 \mathrm{~mL}$ of MA medium, and washed twice by centrifugation (1500 x g, $10 \mathrm{~min})$, decantation and resuspension into MA medium in order to remove EOM components. The cell pellet after the third centrifugation of $M$. aeruginosa was used for the following experiment.

M. aeruginosa cells were suspended in $300 \mathrm{~mL}$ autoclaved tap water at $\mathrm{OD}_{660}$ of $0.0450 \pm 0.0005$ (corresponding to $\mathrm{OD}_{660}$ of a kaolin suspension at $20 \mathrm{mg} / \mathrm{L}$ ), and the alkalinity of the suspension was adjusted to $50 \mathrm{mg} / \mathrm{L}$ with $100 \mathrm{mg} / \mathrm{L}$ of $\mathrm{NaHCO}_{3}$. Then, the $\mathrm{pH}$ value of each sample was adjusted to $7.00 \pm 0.05$, which is the optimal $\mathrm{pH}$ condition for the coagulation with $\mathrm{PACl}$, with $1 \mathrm{~N} \mathrm{HCl}$ or $1 \mathrm{~N} \mathrm{NaOH}$. The concentration of dissolved organic carbon (DOC) of the filtered sample water (cyanobacterial cells are removed by the filtration) was $5.54 \pm 1.51 \mathrm{mg} / \mathrm{L}$, which was measured with TOC-5000 (SHIMADZU, Kyoto, Japan). The DOC constituents in the filtrate is likely to be the residual EOM produced by $M$. aeruginosa, and this concentration of EOM has been proved not to be involved in the coagulation inhibition (Takaara et al., 2007). PACl 
$\left(\mathrm{Al}_{2} \mathrm{O}_{3}: 10.0\right.$ to $\left.11.0 \%\right)$ was added at the concentration between 10 and $130 \mathrm{mg} / \mathrm{L}$, and the suspension was mixed at $80 \mathrm{rpm}$ for $2 \mathrm{~min}\left(\mathrm{G}\right.$ value $\left.=267 \mathrm{~s}^{-1}\right)$ and $30 \mathrm{rpm}$ for 15 $\min \left(G\right.$ value $\left.=61 \mathrm{~s}^{-1}\right)$. Then, the suspension was left for $30 \mathrm{~min}$. The supernatant of each sample $(50 \mathrm{~mL})$ was collected by using a U-shaped pipette in order to avoid the suction of precipitated solids. The $\mathrm{OD}_{660}$ of the collected supernatant was measured by UV1600 (SHIMADZU, Kyoto, Japan).

\section{Preparation of hydrophilic substances from M. aeruginosa}

Cell-associated hydrophilic organic matter was extracted from M. aeruginosa by the phenol-water extraction method (Westphal and Jann, 1965) with minor modifications. Firstly, the cell pellet of washed M. aeruginosa cells was lyophilized by a vacuum freeze dryer (Yamato, Japan). Lyophilized cells of $M$. aeruginosa were suspended in $4 \mathrm{~mL}$ of autoclaved distilled water at $65^{\circ} \mathrm{C}$, and then $4 \mathrm{~mL}$ of $90 \%$ phenol $\left(65^{\circ} \mathrm{C}\right)$ were added. After vigorous stirring with vortex, samples were stirred for $15 \mathrm{~min}$ at $65^{\circ} \mathrm{C}$ and left for $15 \mathrm{~min}$ on ice. Cooled samples were centrifuged at 4,000 x g for 30 min at $2{ }^{\circ} \mathrm{C}$. Components of cell-associated hydrophilic substances were fractionated in the aqueous phase. The aqueous phase $(4 \mathrm{~mL})$ was then mixed with $4 \mathrm{~mL}$ of $90 \%$ phenol at $65^{\circ} \mathrm{C}$. Samples were cooled on ice and centrifuged at $4000 \mathrm{x}$ g for $30 \mathrm{~min}$ at 2 ${ }^{\circ} \mathrm{C}$. The aqueous phase was collected, donated as cyanobacterial hydrophilic compound (CHC), and stored at $-80^{\circ} \mathrm{C}$ until further analysis. 
$\mathrm{CHC}$ was further fractionated by the ethanol precipitation. Four milliliters of $99 \%$ ethanol (chilled at $-20^{\circ} \mathrm{C}$ ) were added to $4 \mathrm{~mL}$ of $\mathrm{CHC}$ and mixed by tumbling. After centrifugation at $15,000 \mathrm{x}$ g for $20 \mathrm{~min}$ at $2{ }^{\circ} \mathrm{C}$, the supernatant was decanted. Then, $2 \mathrm{~mL}$ of $80 \%$ ethanol chilled at $-20{ }^{\circ} \mathrm{C}$ was added to the collected pellet and centrifuged at $15,000 \mathrm{x} \mathrm{g}$ for $20 \mathrm{~min}$ at $2{ }^{\circ} \mathrm{C}$. The supernatant was decanted, and the pellet (hereinafter denoted as CHCpellet) was stored at $-80{ }^{\circ} \mathrm{C}$ until further analysis.

CHCpellet was further fractionated by ultrafiltration. The ultrafiltration was performed by using a polysulphone membrane with a molecular weight cut off (MWCO) of $10 \mathrm{kDa}$ (KURABO, Japan). Prior to the ultrafiltration, the membrane was washed by $20 \mathrm{~mL}$ of double distilled water. CHCpellet was dissolved in $2 \mathrm{~mL}$ of double distilled water, and filtered by the centrifugation at 3,000 x $\mathrm{g}$ for $30 \mathrm{~min}$. The filtrate from CHCpellet (denoted as CHCpellet-filtrate) was sampled and stored at $-80{ }^{\circ} \mathrm{C}$ until further analysis.

Anion exchange chromatography was employed to fractionate CHCpellet based on its net surface charge. Five milliliters of anion exchange resin (ORGANO, Japan) were stuffed into the column, and $15 \mathrm{~mL}$ of $20 \mathrm{mM}$ Tris- $\mathrm{HCl}(\mathrm{pH} 8.0)$ were added. CHCpellet dissolved in $3 \mathrm{~mL}$ of $20 \mathrm{mM}$ Tris- $\mathrm{HCl}$ was applied to the column, and then $2 \mathrm{~mL}$ of $20 \mathrm{mM}$ Tris- $\mathrm{HCl}(\mathrm{pH} \mathrm{8.0)}$ were sequentially added to the column. Six milliliters of the permeate from the column, including positively- and non-charged CHCpellet (CHCpellet-anion exchanged), were collected at the column outlet and 
stored at $-80^{\circ} \mathrm{C}$ until further analysis.

CHCpellet was treated with RNase A to eliminate RNA components. CHCpellet dissolved in $2 \mathrm{~mL}$ of double distilled water was treated with RNase A of 100 $\mu \mathrm{g} / \mathrm{mL}$ (SIGMA, Japan) for $6 \mathrm{hrs}$ at $37^{\circ} \mathrm{C}$. After the RNase A treatment, remaining organic matter was purified by the ethanol precipitation as already described. The degradation of RNA molecules by the RNase A treatment was visibly confirmed by the agarose gel (1.5\%) electrophoresis, ethidium bromide staining and UV light excitation. The collected pellet after the ethanol precipitation was donated as CHCpellet-RNase treated, and stored at $-80{ }^{\circ} \mathrm{C}$ until further analysis.

\section{Coagulation test of kaolin suspension in the presence of cell-associated hydrophilic} substances from M. aeruginosa

Coagulation test of suspended kaolin using PACl was performed in order to investigate the contribution of $\mathrm{CHC}$, CHCpellet, CHCpellet-filtrate and CHCpellet-anion exchanged to coagulation inhibition. The occurrence of the coagulation inhibition was assessed by the difference in $\mathrm{OD}_{660}$ of the supernatant after the sedimentation of coagulated kaolin in the presence or absence of $\mathrm{CHC}$ as described previously (Takaara et al., 2007). Kaolin (23000-02, Kanto, Tokyo, Japan) was added to autoclaved tap water at a final concentration of $20 \mathrm{mg} / \mathrm{L}$, and alkalinity was adjusted to $50 \mathrm{mg} / \mathrm{L}$ with $100 \mathrm{mg} / \mathrm{L}$ of $\mathrm{NaHCO}_{3}$. Then, the $\mathrm{pH}$ value of each sample was adjusted to 
$7.00 \pm 0.05$ with $1 \mathrm{~N} \mathrm{HCl}$ or $1 \mathrm{~N} \mathrm{NaOH}$. This suspension was used as the control in the coagulation test. The test samples were separately prepared by adding each fractionated CHC into the kaolin suspension as shown in Table 1 . Then, the quantity of kaolin was adjusted to the final concentration of $20 \mathrm{mg} / \mathrm{L}$, and the $\mathrm{pH}$ was adjusted to $7.00 \pm 0.05$ with $1 \mathrm{~N} \mathrm{HCl}$ or $1 \mathrm{~N} \mathrm{NaOH}$. Two hundred milliliters of each test sample were poured into a $200-\mathrm{mL}$ glass beaker and agitated with a shaking apparatus at $80 \mathrm{rpm}$ for $1 \mathrm{~min}$. Then, PACl was added to each sample at a concentration of $20 \mathrm{mg} / \mathrm{L}$, and the sample was mixed at $80 \mathrm{rpm}$ for $2 \mathrm{~min}\left(\mathrm{G}\right.$ value $\left.=267 \mathrm{~s}^{-1}\right)$ and $30 \mathrm{rpm}$ for $15 \mathrm{~min}\left(\mathrm{G}\right.$ value $\left.=61 \mathrm{~s}^{-1}\right)$. Samples were left for $30 \mathrm{~min}$, and then the supernatant of each sample $(50 \mathrm{~mL})$ was collected by using a U-shaped pipette in order to avoid the suction of precipitated solids. The $\mathrm{OD}_{660}$ of the collected supernatant was measured by UV1600.

A coagulation test of the suspended kaolin in the presence of CHCpellet-RNase treated was separately performed to investigate the contribution of SOM from $M$. aeruginosa to coagulation inhibition. The amount of CHCpellet-RNase fractionated from cyanobacterial culture is far smaller than other fractions such as CHCpellet-filtrate and CHCpellet-anion exchanged. Therefore, it was necessary for us to conduct the coagulation test with CHCpellet-RNase in a smaller scale, and we adjusted the experimental conditions. SOM (CHCpellet-RNase treated) was added to autoclaved tap water, and test solutions at different concentrations of SOM (17 to 516 mg-C/L) were prepared. Kaolin was added to the solution at a final concentration of 20 
$\mathrm{mg} / \mathrm{L}$, and alkalinity was adjusted to $50 \mathrm{mg} / \mathrm{L}$ with $100 \mathrm{mg} / \mathrm{L}$ of $\mathrm{NaHCO}_{3}$. Then, the $\mathrm{pH}$ value of each sample was adjusted to $7.00 \pm 0.05$ with $1 \mathrm{~N} \mathrm{HCl}$ or $1 \mathrm{~N} \mathrm{NaOH}$. Fifty milliliters of samples were used for the coagulation test. After test samples were agitated thoroughly, $\mathrm{PACl}$ was added to each sample at a final concentration of $10 \mathrm{mg} / \mathrm{L}$. Then, the samples were mixed at $100 \mathrm{rpm}$ for $2 \min \left(\mathrm{G}\right.$ value $\left.=162 \mathrm{~s}^{-1}\right)$ and $50 \mathrm{rpm}$ for $15 \mathrm{~min}\left(\mathrm{G}\right.$ value $\left.=57 \mathrm{~s}^{-1}\right)$. Samples were left for $10 \mathrm{~min}$, and then the supernatant of each sample $(25 \mathrm{~mL})$ was collected. The $\mathrm{OD}_{660}$ of collected supernatant was measured by UV1600.

\section{Results and discussion}

\section{Coagulation efficiency of M. aeruginosa cells with PACI}

The coagulation test for $M$. aeruginosa cells using $\mathrm{PACl}$ was performed to determine the presence of inhibitory substances on the surface of $M$. aeruginosa NIES-91. EOM was washed away, and cells of M. aeruginosa suspended in autoclaved tap water at the turbidity corresponding to the kaolin suspension of $20 \mathrm{mg} / \mathrm{L}$ were used. The kaolin suspension at $20 \mathrm{mg} / \mathrm{L}$ was employed as a control for the coagulation test of M. aeruginosa cells. Fig. 2 shows the reduction rate of $\mathrm{OD}_{660}$ in the coagulation test of M. aeruginosa cells with PACl. Suspended kaolin was well coagulated with $20 \mathrm{mg} / \mathrm{L}$ of 
$\mathrm{PACl}$ (the reduction rate of $\mathrm{OD}_{660}$ was $92.7 \%$ ), while strong coagulation inhibition was observed when the cell suspension of $M$. aeruginosa was destabilized by $50 \mathrm{mg} / \mathrm{L}$ or less concentration of $\mathrm{PACl}$ (the reduction rate was less than $5 \%$ ). Seventy milligrams per litter of $\mathrm{PACl}$ were required to obtain the $\mathrm{OD}_{660}$ reduction rate of $93.8 \%$ for the cell suspension of $M$. aeruginosa. The strong inhibition of coagulation with $\mathrm{PACl}$ could be attributed to the cell-associated substances of $M$. aeruginosa, because the concentration of DOC was too low $(5.54 \pm 1.51 \mathrm{mg} / \mathrm{L})$ to cause the coagulation inhibition as proved by our previous study (Takaara et al., 2007). The contribution of cytoplasmic proteins to coagulation inhibition also can be ignored because cell destruction, represented by the change of color and the increase in organic matter in test water, did not occur during the destabilization. Since the flocculation of cyanobacterial cells was not observed at the $\mathrm{PACl}$ concentration of less than $50 \mathrm{mg} / \mathrm{L}$, the aluminum speciation that is important for the coagulant to exert the coagulation capability (Zhao et al., 2009) seemed to be hampered by inhibitors possibly located on the surface of cyanobacterial cells. Since the majority of AOM located on the cyanobacterial cell surface could be hydrophilic carbohydrate substances, the involvement of cyanobacterial hydrophilic substances extracted from $M$. aeruginosa cells in the coagulation inhibition is analyzed in the following sections.

Involvement of $\mathrm{CHC}$ from $M$. aeruginosa in the coagulation inhibition 
Fig. 3 shows the reduction rate of $\mathrm{OD}_{660}$ on the coagulation of suspended kaolin in the presence or absence of CHC from M. aeruginosa. Suspended kaolin was well coagulated with $\mathrm{PACl}$ in the absence of $\mathrm{CHC}$, in which the reduction rate of $\mathrm{OD}_{660}$ reached $91.6 \%$. On the other hand, the reduction rate of $\mathrm{OD}_{660}$ was dramatically reduced in the presence of $\mathrm{CHC}(13.3 \%)$, which means that $\mathrm{CHC}$ from $M$. aerugionosa includes potent inhibitory substances for coagulation using PACl. The phenol-water extraction, which was employed to obtain $\mathrm{CHC}$ from $M$. aerugionosa in this study, is the method for isolating LPS of gram-negative bacteria, and the extract contains LPS and RNA at a ratio of 1:1 (Westophal and Jann, 1965). Components of the slime layer on the surface of $M$. aeruginosa cells could be also included in the extract because it is unlikely that the cell-associated slime layer was completely washed out during the cell collection step. However, the amount of slime layer constituents would be much less than that of LPS because excess production of the slime layer was not observed in the $M$. aeruginosa cell stock. This is why the low coagulation efficiency in the presence of CHC implies that RNA and/or LPS from $M$. aeruginosa caused coagulation inhibition.

Ethanol precipitation was employed as the first step to fractionate CHC. After ethanol precipitation, the precipitate was stored and denoted as CHCpellet. CHCpellet included $84( \pm 37) \%$ of $\mathrm{CHC}$ on the carbon basis. Coagulation using PACl was considerably inhibited in the presence of $\mathrm{CHCpellet}$ (the $\mathrm{OD}_{660}$ reduction rate was $12.8 \%$ ), which means that the potent inhibitory substances in $\mathrm{CHC}$ were fractionated in 
CHCpellet.

In order to obtain the information on the molecular weight of the inhibitory substances, CHCpellet was further fractionated by ultrafiltration. CHCpellet-filtrate was the permeate separated from CHCpellet by the ultrafiltration with MWCO of $10 \mathrm{kDa}$. Suspended kaolin was well coagulated with $20 \mathrm{mg} / \mathrm{L} \mathrm{PACl}$ in the presence of CHCpellet-filtrate, in which the reduction rate of $\mathrm{OD}_{660}$ reached $80.5 \%$. This coagulation efficiency in the presence of CHCpellet-filtrate was significantly higher than that of CHCpellet (12.8\%). The lower DOC concentration in CHCpellet-filtrate (Table 1) might contribute to the improvement of reduction efficiency of suspended solids. However, the DOC concentration in the test water including CHCpellet-filtrate was high enough to cause coagulation inhibition if coagulation inhibitors are the main components (Takaara et al., 2007). Therefore, it is considered that the coagulation inhibitors of interest are hardly included in the test water, and potent inhibitory substances are unlikely to be in the permeate by the ultrafiltration.

CHCpellet was also fractionated by anion exchange chromatography. CHCpellet-anion exchanged is the permeate from the anion exchange column when CHCpellet was introduced. Theoretically, CHCpellet-anion exchanged contains positively and noncharged substances in CHCpellet. The suspended kaolin was well coagulated with $20 \mathrm{mg} / \mathrm{L} \mathrm{PACl}$ when CHCpellet-anion exchanged was included (the reduction rate of $\mathrm{OD}_{660}$ was $76.1 \%$ ). These results lead to the speculation that the 
coagulation inhibition is mainly caused by negatively-charged substances in CHCpellet.

As a result, it is estimated that negatively charged hydrophilic substances with a molecular weight higher than $10 \mathrm{kDa}$ could have a significant role in coagulation inhibition. Both LPS and RNA, the main components of CHCpellet, coincide with the criteria. In particular, LPS from $M$. aeruginosa could be suspected to be a plausible inhibitor, since LPS is located on the surface of the $M$. aeruginosa cells, and could be involved in coagulation inhibition without cell destruction as shown in Fig. 2. Although nucleotides can interact with aluminum (Kiss et al., 1996; Rubini et al., 2002), which raises the possibility of the interaction of RNA with components of the coagulant, RNA molecules existing in a cellular cytoplasm are difficult to contribute to the coagulation inhibition without the destruction of cyanobacterial cells. The vulnerability of RNA molecules in natural environment (Limsawat and Ohgaki, 1997) also should be taken into account to explain the factors of coagulation inhibition. Based on these discussions, we assayed in the following section the involvement of the CHCpellet-RNase treated, which are mainly composed of SOM, including LPS from M. aeruginosa, in the coagulation inhibition.

\section{Involvement of CHCpellet-RNase treated in coagulation inhibition}

In order to investigate the contribution of SOM from $M$. aeruginosa to the reduction of coagulation efficiency, the coagulation test using suspended kaolin with 
$\mathrm{PACl}$ in the presence of CHCpellet-RNase treated was performed. Fig. 4 shows a reduction rate of $\mathrm{OD}_{660}$ on the coagulation test in the presence of CHCpellet-RNase treated. The $\mathrm{OD}_{660}$ reduction rate of more than $90 \%$ was obtained when the concentration of CHCpellet-RNase treated was lower than $48 \mathrm{mg}$-carbon/L. However, the reduction of the coagulation efficiency was observed when the concentration of CHCpellet-RNase treated exceeded $55 \mathrm{mg}$ - carbon/L. Then, coagulation with $10 \mathrm{mg} / \mathrm{L}$ PACl was completely inhibited (i.e., no flocculation was observed) when the concentration of CHCpellet-RNase treated reached $103 \mathrm{mg}$-carbon/L. These results indicate that CHCpellet-RNase treated significantly contributed to coagulation inhibition. It is suggested that the hydrolysis of $\mathrm{PACl}$, which is required to exert a coagulation capability (Zhao et al., 2009), was strongly impeded by the presence of CHCpellet-RNase treated, since a strong inhibition against the formation of flocculation was observed.

If the majority of organic matter in CHCpellet-RNase treated consists of LPS, the concentration of CHCpellet-RNase treated that brought about the potent coagulation inhibition (103 mg-carbon/L) corresponds to about $10^{13}$ cells/L of $M$. aeruginosa according to the literature value of the LPS contents in a gram-negative bacterial cell (Raetz and Whitfield, 2002). This concentration of M. aeruginosa can be attained by the excess growth of cyanobacteria in semi-closed water areas (Zohary and Madeila, 1990), which supports the speculation that LPS from M. aeruginosa is a potent inhibitory 
substance for coagulation. However, further evaluation is required to confirm that LPS from $M$. aeruginosa is the main inhibitory substances in the destabilization step with $\mathrm{PACl}$ as coagulant. For example, it should be noted that LPS molecules in CHC were used in a dispersed state in the coagulation test, but these molecules were originally located on the surface of a $M$. aeruginosa cells as components of its outer membrane. The interaction between LPS located on the cell surface of $M$. aeruginosa and coagulants needs to be analyzed in a future study. The components analysis of LPS from M. aeruginosa also contributes to the identification of the critical moieties in LPS causing coagulation inhibition. Outputs from these next challenges could create effective countermeasures against the problems of coagulation inhibition in drinking water production.

\section{Conclusions}

The involvement of cyanobacterial hydrophilic compound (CHC) from $M$. aeruginosa in the coagulation inhibition was investigated. Negatively-charged CHC with a molecular weight higher than $10 \mathrm{kDa}$ would have a significant role in coagulation inhibition. Lipopolysaccharide (LPS) and/or RNA from M. aeruginosa were suspected to be strong inhibitors for the coagulation. CHC treated by RNase A also exhibited strong inhibition in the coagulation using $\mathrm{PACl}$, which leads to the speculation that LPS could have an important role in coagulation inhibition. The concentration of 
CHC treated by RNase A that causes the coagulation inhibition was $103 \mathrm{mg}$-carbon/L. This concentration of $\mathrm{CHC}$ corresponds to $10^{13} \mathrm{M}$. aeruginosa cells/L, which can be observed when the excess growth of $M$. aeruginosa in freshwater occurs. The components analysis of LPS could provide important information on the mechanisms of coagulation inhibition caused by $M$. aeruginosa

\section{Acknowledgement}

This work has been funded in part by Grant-in-Aid for JSPS Fellows from Japan Society for the Promotion of Science (JSPS) and Grant-in-Aid for Young Scientists (B) in the Ministry of Education, Culture, Sports, Science and Technology (MEXT) of Japan. We thank Mr. Takeshi Suto for his technical support during this work.

\section{References}

Bernhardt, H., Hoyer, O., Lusse, B., Schell, H., 1987. Investigations on the influence of algal-derived organic substances on flocculation and filtration. In: Huck, P.H. and Toft, P. (Eds.), Treatment of drinking water for organic contaminants. Proceedings of the second national conference on drinking water, Pergamon Press, New York, 185-216.

Bernhardt, H., Shell, H., Hoyer, O., Lusse, B., 1991. Influence of algogenic organic 
substances on flocculation and filtration. Wat. Inst. S. Africa, 1, 41-57.

Cheng, W.P., Chi, F.H., 2003. Influence of eutrophication on the coagulation efficiency in reservoir water. Chemosphere, 53, 773-778.

Hitzfeld, B.C., Hoger, S.J., Dietrich, D.R., 2000. Cyanobacterial toxins: removal during drinking water treatment, and human risk assessment. Environ. Health Perspec. 108(S1), 113-122.

Hoyer, O., Lusse, B., Berhnhardt, H., 1985. Isolation and characterization of extracellular organic matter (EOM) from algae. Z. Wasser-Abwasser-Forsch, 18, 76-90.

Huang, J., Graham, N., Templeton, M.R., Zhang, Y., Collins, C., Nieuwenhuijsen, M., 2009. A comparison of the role of two blue-green algae in THM and HAA formation. Wat. Res. 43, 3009-3018.

Ichimura, T., 1979. Media for blue-green algae, In Nishizawa, K., Chihara, M. (Eds.), Methods in algalogical studies. Kyoritsu, Tokyo, 294-305 (in Japanese).

Jun, H.B., Lee, Y.J., Lee, B.D., Knappe, D.R.U., 2001. Effectiveness of coagulants and coagulant aids for the removal of filter-clogging Synedra, J. Water Supply Res. Technol.-Aqua. 50(3), 135-148.

Jürgens, U.J., Martin, C., Weckesser, J., 1989. Cell wall constituents of Microcystis sp. PCC 7806, FEMS Microbiol. Let. 65(1-2), 47-51. 
Kiss, T., Zatta, P., Corain, B., 1996. Interaction of aluminum (III) with phosphate-binding sites: biological aspects and implications, Coordin. Chem. Rev. 149, 329-346.

Limsawat, S., Ohgaki, S. 1997. Fate of liberated viral RNA in wastewater determined by PCR. Appl. Environ. Microbiol. 63(7), 2932-2933.

Liu, Z., Bernhardt, H., 1991. Effects of chlorination of algogenic organic matter on flocculation, Z. Wasser-Abwasser-Forsch, 24, 70-75.

Ma, J., Lei, G., Fang, J., 2007. Effect of algae species population structure on their removal by coagulation and filtration processes - a case study. J. Water Supply Res. Technol.-Aqua. 56(1), 41-54.

Ma, J., Liu, W., 2002. Effectiveness and mechanism of potassium ferrate(VI) preoxidation for algae removal by coagulation. Wat. Res. 36, 871-878.

Parker, D.L., Schram, B.R., Plude, J.L. Moore, R.E., 1996. Effect of metal cations on the viscosity of a pectin-like capsular polysaccharide from the cyanobacterium Microcystis flosaquae C3-40. Appl. Environ. Microbiol. 62(4), 1208-1213.

Pivokonsky, M., Kloucek, O., Pivokonska, L., 2006. Evaluation of the production, composition and aluminum and iron complexation of algogenic organic matter, Wat. Res. 40, 3045-3052.

Plude, J.L., Parker, D.L., Schommer, O.J., Timmerman, R.J., Hagstrom, S.A., Joers, J.M., Hnasko, R., 1994. Chemical characterization of polysaccharide from the slime 
layer of the cyanobacterium Microcystis flosaquae C3-40, Appl. Environ. Microbiol. 57(6), 1696-1700.

Raetz, C.R.H., Whitfield, C., 2002. Lipopolysaccharide endotoxins, Annu. Rev. Biochem. 71, 635-700.

Rubini, P., Lakatos, A., Champmartin, D., Kiss, T., 2002. Speciation and structural aspects of interaction of $\mathrm{Al}$ (III) with small biomolecules, Coordin. Chem. Rev. 228, 137-152.

Takaara, T., Sano, D., Konno, H., Omura,T., 2005. Affinity isolation of algal organic matters able to form complex with aluminum coagulant, Wat. Sci. Technol. 4(5-6), 95-102.

Takaara, T., Sano, D., Konno, H., Omura, T., 2007. Cellular proteins of Microcystis aeruginosa inhibiting coagulation with polyaluminum chloride, Wat. Res. 41,1653-1658.

Westphal, O., Jann, K., 1965. Bacterial lipopolysaccharides, In Whistler, R.L., Wolfrom, M.L. (Eds.), Methods in carbohydrate chemistry, Academic Press Inc. New York, 83-91.

Westerhoff, P., Rodrigues, M., Baker, L., Sommerfeld, M. 2005. Seasonal occurrence and degradation of 2-methylisoborneol in water supply reservoirs. Wat. Res. 39(20), 4899-4912.

Widrig, D.L., Gray, K.A., McAuliffe, K.S. 1996. Removal of algal-derived organic 
material by preozonation and coagulation: monitoring changes in organic quality by pyrolysis-GC-MS. Wat. Res. 30(11), 2621-2632.

Zhao, H., Liu, H., Hu, C., Qu, J., 2009. Effect of aluminum speciation and structure characterization on preferential removal of disinfection byproduct precursors by aluminum hydroxide coagulation. Environ. Sci. Tech. 43, 5067-5072.

Zohary, T., Madeila, A.M.P., 1990. Structural, physical and cyhemical characteristics of Microcystis aeruginosa hyperscums from a hypereutrophic lake, Freshwater Biol. 23, 339-352.

\section{List of Figures}

Fig. 1. Flow chart of the experiments in this study, including the preparation of cyanobacterial hydrophilic substances and the coagulation test using polyaluminum chloride.

Fig. 2. Coagulation test of M. aeruginosa cells using polyaluminum chloride. Kaolin suspension was used as a control. Error bars indicate standard deviations in triplicate.

Fig. 3. Reduction rate of optical density at $660 \mathrm{~nm}$ in the coagulation test of kaolin 
suspension using polyaluminum chloride in the presence of cyanobacterial hydrophilic substances. Kaolin suspension was used as a control. Error bars indicate standard deviations in triplicate. Sample codes correspond to those in Table 1.

Fig. 4. Coagulation test of suspended kaolin using $10 \mathrm{mg} / \mathrm{L}$ polyaluminum chloride in the presence of RNase treated-cyanobacterial hydrophilic substances. Error bars indicate standard deviations in triplicate. 
Table 1. Composition of samples used in the coagulation test with polyaluminum chloride

\begin{tabular}{|c|c|c|c|c|}
\hline \multirow[b]{2}{*}{ Sample code } & \multirow[b]{2}{*}{ Description } & \multicolumn{2}{|c|}{ Volume (mL) } & \multirow{2}{*}{$\begin{array}{c}\mathrm{DOC} \pm \mathrm{SD} \\
(\mathrm{mg} / \mathrm{L})\end{array}$} \\
\hline & & $\begin{array}{c}\text { Cyanobacterial } \\
\text { hydrophilic substances }\end{array}$ & $\begin{array}{c}\text { Autoclaved } \\
\text { tap water }\end{array}$ & \\
\hline $\mathrm{CHC}$ & $\begin{array}{c}\text { Extracts by } \\
\text { phenol/water method }\end{array}$ & 6 & 294 & $338 \pm 60$ \\
\hline CHCpellet & $\begin{array}{l}\text { Precipitation by } \\
\text { ethanol precipitation }\end{array}$ & 1 & 299 & $283 \pm 22$ \\
\hline CHCpellet-filtrate & $\begin{array}{c}\text { Permeate by } \\
\text { ultrafiltration } \\
(\mathrm{MWCO} \text { is } 10 \mathrm{kDa})\end{array}$ & 1 & 299 & $63 \pm 22$ \\
\hline $\begin{array}{l}\text { CHCpellet-anion } \\
\text { exchanged }\end{array}$ & $\begin{array}{c}\text { Permeate from anion } \\
\text { exchange } \\
\text { chromatography }\end{array}$ & 6 & 294 & $166 \pm 44$ \\
\hline
\end{tabular}


Fig. 1

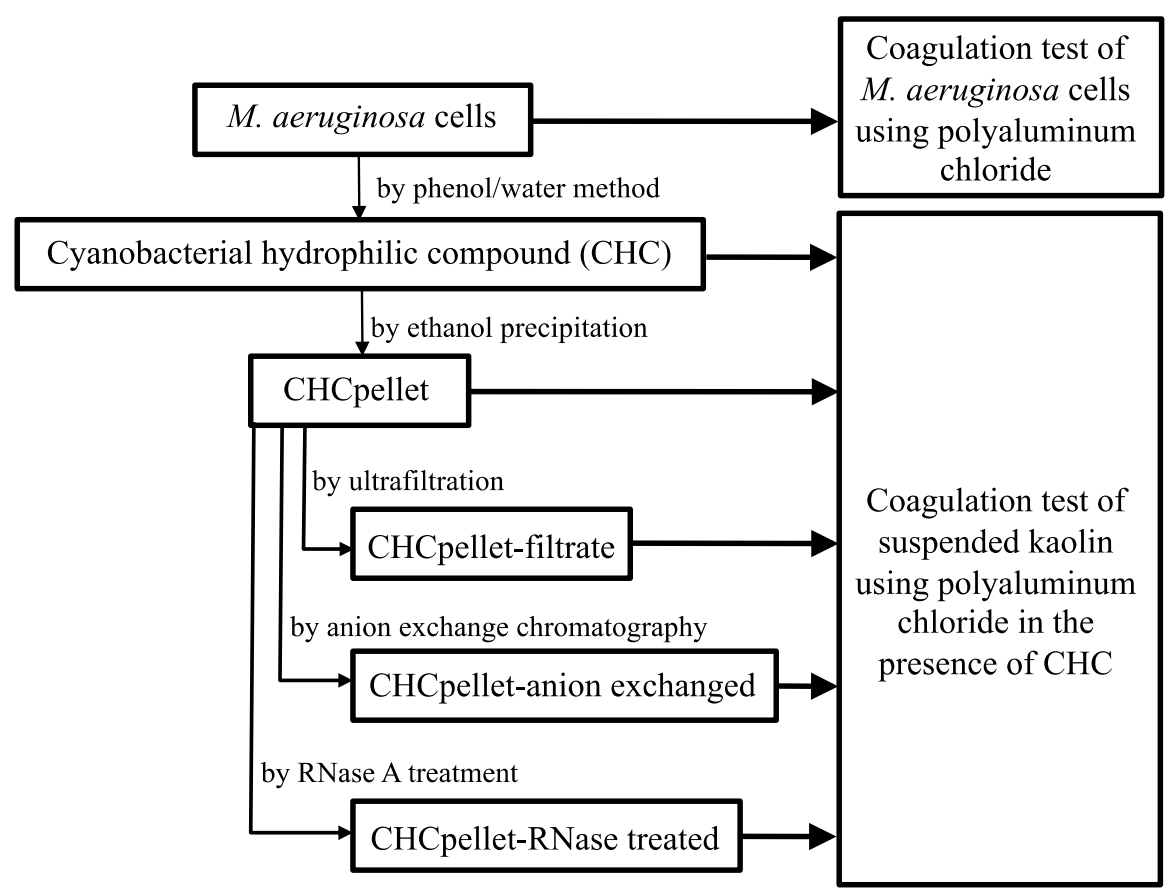


Fig. 2

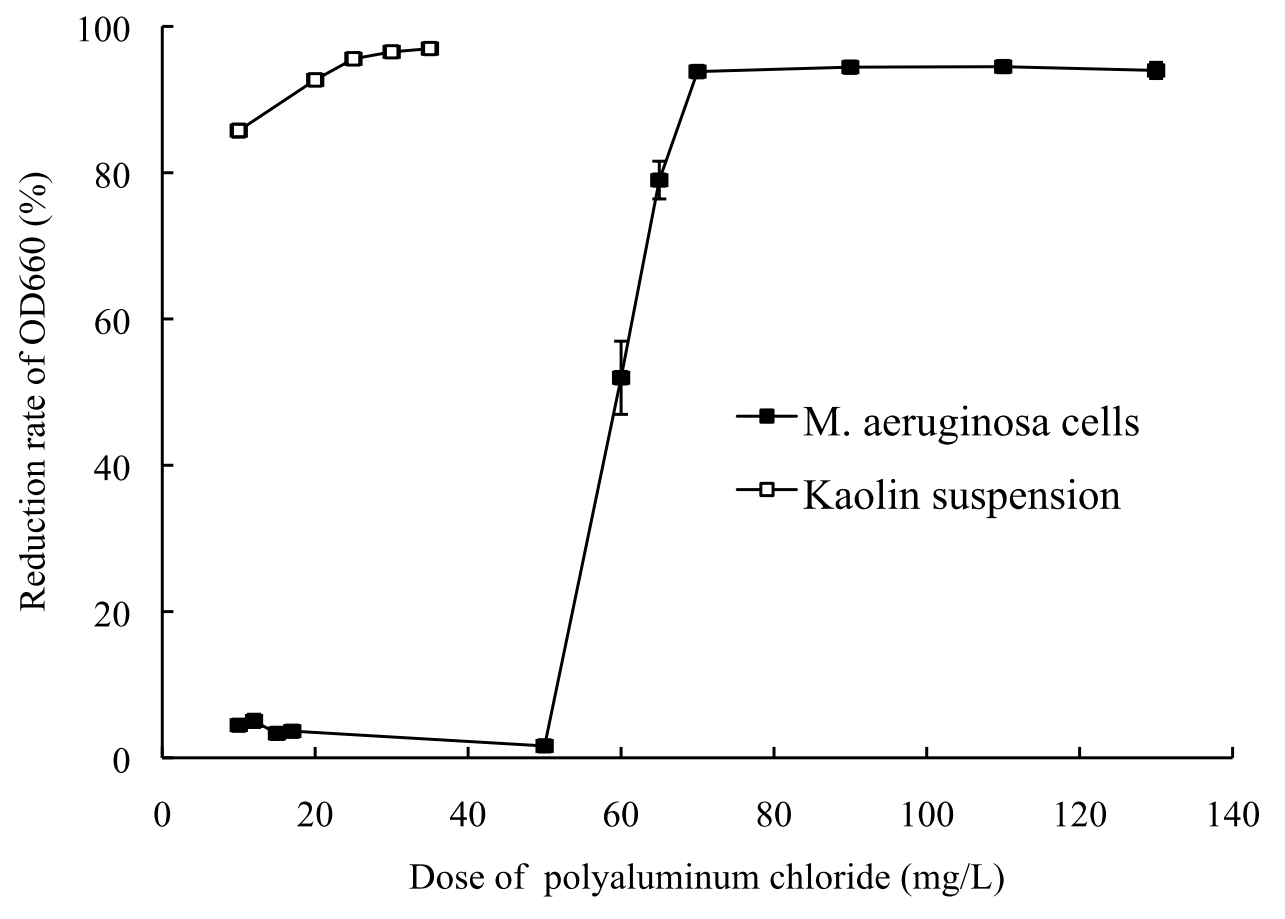


Fig. 3

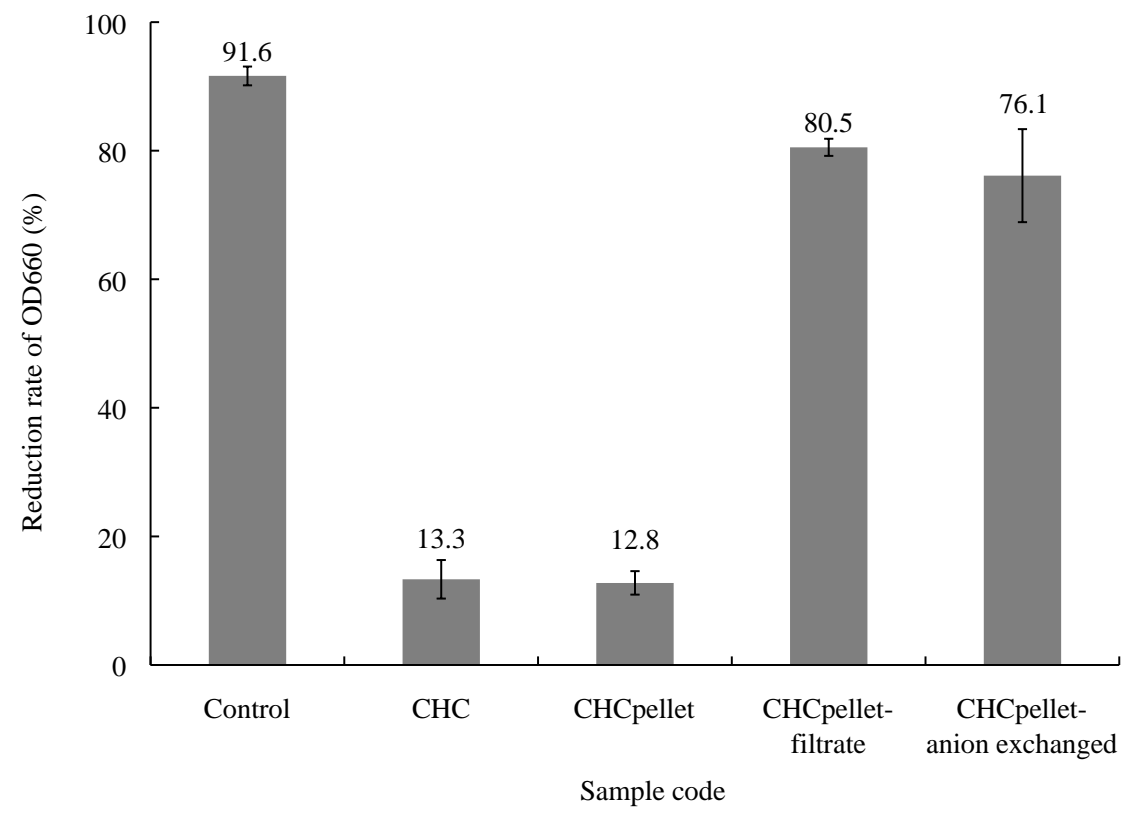


Fig. 4

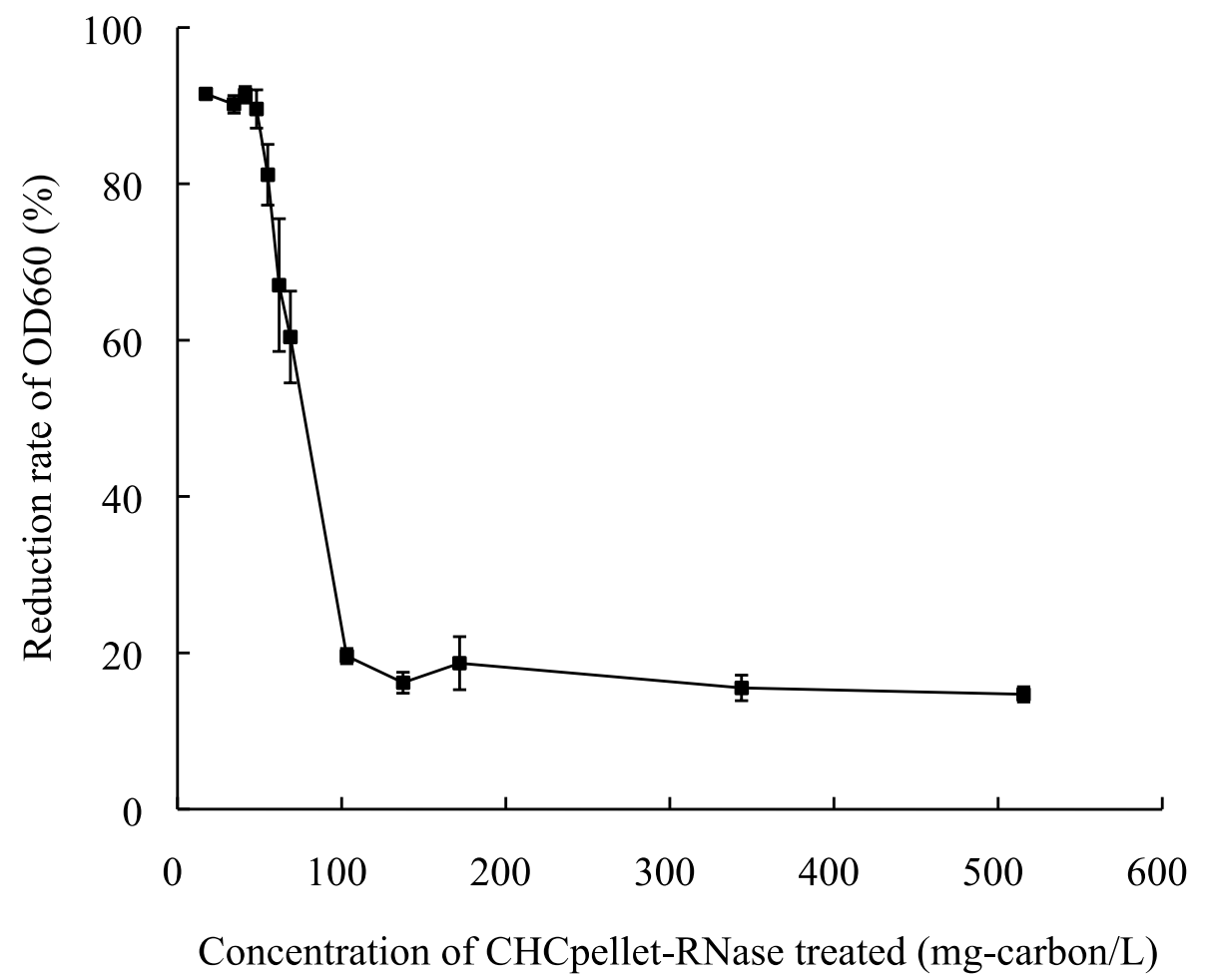

